\title{
Het wetsvoorstel wettelijke bedenktijd beursvennootschappen onderzocht
}

H. Koster

\section{$1 \quad$ Inleiding}

Op 18 december 2019 is het wetsvoorstel 'Wijziging van Boek 2 van het Burgerlijk Wetboek in verband met het inroepen van een bedenktijd door het bestuur van een beursvennootschap' bij de Tweede Kamer ingediend. ${ }^{1}$ De voorgestelde wettelijke regeling behelst dat het bestuur op basis van het voorgestelde art. 2:114b BW de mogelijkheid heeft een bedenktijd van maximaal 250 dagen in te roepen. Hiermee krijgt het bestuur de tijd voor inventarisatie en weging van de belangen van de onderneming en de stakeholders als zich bepaalde omstandigheden voordoen. Gedachte is dat met dit voorstel wordt voorkomen dat kortetermijnbelangen van aandeelhouders, bijvoorbeeld bij een dreigende vijandige overname, een zorgvuldige afweging van de effecten op de onderneming in de weg staan. Het wetsvoorstel bevat waarborgen om oneigenlijk gebruik van de bedenktijd tegen te gaan. Het voorontwerp geeft uitvoering aan het regeerakkoord, waarin een dergelijke regeling al was benoemd. ${ }^{2}$ Daarnaast bevat het wetsvoorstel een codificerende aanvulling van de wettelijke omschrijving van de bestuurstaak in art. 2:129 lid 1 BW. Beide voorgestelde bepalingen zijn uitsluitend gericht op naamloze en besloten beursvennootschappen. ${ }^{3}$ In dit artikel ${ }^{4}$ onderzoek ${ }^{5}$ ik dit voorstel. ${ }^{6}$

1 Kamerstukken II 2019/20, 35367, nrs. 1-4.

2 'Vertrouwen in de toekomst', regeerakkoord 2017-2021, p. 34. Zie in dit kader ook H.J. de Kluiver, Modernisering ondernemingsrecht; waarheen, waarvoor?, Ondernemingsrecht 2017/118. Ook wordt met het wetsvoorstel uitvoering gegeven aan de motie-Van Rooijen (Kamerstukken II 2016/17, 29826, nr. 87) en de motie-Paternotte c.s. (Kamerstukken II 2016/17, 29826, nr. 89).

3 Op 7 december 2018 was een voorontwerp van het wetvoorstel ter consultatie gepubliceerd. Dat zag alleen op naamloze beursvennootschappen. Zie www.internetconsultatie.nl/ wetsvoorstelbedenktijd voor het conceptwetsvoorstel. Zie hierover mijn bijdrage: H. Koster, Consultatievoorstel wettelijke bedenktijd naamloze beursvennootschappen, A\&O 2019, afl. 1, p. 38-45.

$4 \quad$ Voor deze bijdrage heb ik geput uit Koster 2019.

5 Aan de vraag of dit wetsvoorstel toegevoegde waarde heeft, heb ik al eerder aandacht besteed. Op die vraag ga ik daarom in deze bijdrage niet opnieuw in. Zie hierover Koster 2019. Zie ook kritisch H.M. Vletter-van Dort, De bedenktijd: naïef of noodzaak?, Ondernemingsrecht 2019/161.

6 Zie over dit wetsvoorstel ook M. van Olffen, Wetsvoorstel wettelijke bedenktijd beursvennootschappen, Ondernemingsrecht 2020/51, C.J.C. de Brauw, Nut en noodzaak van de wettelijke bedenktijd bij strategiebepaling en het bestaande raamwerk van beschermingsmogelijkheden, Ondernemingsrecht 2020/52 en L.F. Groothuis, Toepassing van de wettelijke bedenktijd in de (proces)praktijk, Ondernemingsrecht 2020/53. 


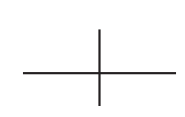

H. Koster

\section{Het beleid en de strategie van de vennootschap}

Voorgesteld wordt om art. 2:129 lid 1 BW als volgt te formuleren:

'1. Behoudens beperkingen volgens de statuten is het bestuur belast met het besturen van de vennootschap. Voor een vennootschap waarvan de aandelen of met medewerking van de vennootschap uitgegeven certificaten van aandelen zijn toegelaten tot de handel op een gereglementeerde markt of een multilaterale handelsfaciliteit als bedoeld in artikel 1:1 van de Wet op het financieel toezicht of een met een gereglementeerde markt of multilaterale handelsfaciliteit vergelijkbaar systeem uit een staat die geen lidstaat is, is daaronder in ieder geval begrepen het bepalen van het beleid en de strategie van de vennootschap.'

Het gecursiveerde deel van de wettekst is nieuw. Door aanpassing van de schakelbepaling art. 2:187 BW gaat dit ook gelden voor besloten beursgenoteerde vennootschappen. ${ }^{7}$ Naar huidig recht bepaalt dit artikellid alleen dat het bestuur het vennootschapsorgaan is dat belast is met het besturen van de vennootschap behoudens beperkingen volgens de statuten. ${ }^{8}$ De voorgestelde aanvulling betreft codificatie. ${ }^{9}$ Op basis van de jurisprudentie geldt nu reeds dat het bepalen van de strategie in beginsel een aangelegenheid is van het bestuur onder toezicht van de raad van commissarissen $(\mathrm{RvC}) .{ }^{10}$ Ook geldt nu al dat het bestuur over zijn beleid verantwoording moet afleggen aan de algemene vergadering (AV). ${ }^{11} \mathrm{Bij}$ de vervulling van de aan het bestuur bij wet of statuten opgedragen taken, waaronder dus de strategie en het beleid, moet het bestuur het belang van de vennootschap en de daaraan verbonden onderneming vooropstellen en de belangen van alle betrokkenen, waaronder die van de aandeelhouders, bij zijn besluitvorming in aanmerking nemen. ${ }^{12}$ De AV kan haar opvattingen daarover tot uitdrukking brengen door uitoefening van de haar in de wet en statuten toegekende rechten. Behoudens afwijkende wettelijke of statutaire regelingen is het bestuur evenwel niet verplicht de $\mathrm{AV}$ vooraf in zijn besluitvorming te betrekken als het gaat om handelingen waar-

7 Art. 2:187 is ingevoerd door het voorstel tot Wijziging van Boek 2 van het Burgerlijk Wetboek, de Wet op het financieel toezicht en de Wet giraal effectenverkeer ter uitvoering van Richtlijn 2017/828/EU van het Europees Parlement en de Raad van 17 mei 2017 tot wijziging van Richtlijn 2007/36/EG wat het bevorderen van de langetermijnbetrokkenheid van aandeelhouders betreft (PbEU 2017, L 132) (Kamerstukken 35058). In dit wetsartikel is een aantal bepalingen van toepassing verklaard op besloten vennootschappen met beursnotering. Voor de toepassing van het voorgestelde art. 2:114b lid $10 \mathrm{BW}$ is van belang dat in het bv-recht geen onderscheid (meer) wordt gemaakt tussen certificaten die met respectievelijk zonder medewerking van de vennootschap zijn uitgegeven. Daarom is bepaald dat voor certificaten respectievelijk certificaathouders moet worden gelezen dat het gaat om certificaten waaraan vergaderrecht is verbonden respectievelijk certificaathouders aan wie het vergaderrecht toekomt.

8 Daarnaast heeft het bestuur een onbeperkte en onvoorwaardelijke bevoegdheid om de vennootschap te vertegenwoordigen bij het aangaan van rechtshandelingen, tenzij uit de wet anders voortvloeit. Zie art. 2:130 BW.

9 Kamerstukken II 2019/20, 35367, nr. 3, p. 10.

10 HR 13 juli 2007, ECLI:NL:HR:2007:BA7970 (ABN AMRO), r.o. 4.3.

11 Idem.

12 HR 9 juli 2010, ECLI:NL:HR:2010:BM0976 (ASMI), r.o. 4.4.1. 
(memorie van toelichting bij wetsvoorstel bijzondere maatregelen door de Ondernemingskamer over de zeggenschap, Kamerstukken II, 1997-98, 25 732, nr. 3, p. 21). Het gaat dan om zodanige situatie dat de continuïteit, onafhankelijkheid, identiteit of ontplooiing van de vennootschap op het spel staat. $^{35}$

In het kader van het inroepen dan wel het goedkeuren van de bedenktijd kan een tegenstrijdig belang aan de orde zijn bij bestuur respectievelijk $\mathrm{RvC}$, waardoor de AV bevoegd wordt. Het is de vraag of dat wenselijk is en ook of dat de toepassing van deze regeling in feite niet zal verhinderen. Overigens geldt dat indien het ontslag van een of meer bestuurders of commissarissen wordt verzocht, dit op zichzelf bezien geen tegenstrijdig belang oplevert wanneer het bestuur het inroepen van de bedenktijd overweegt. ${ }^{36}$ Maar onder omstandigheden kan dat anders komen te liggen. Tegenstrijdig belang kan bijvoorbeeld wel aan de orde zijn als een bestuurder een overeenkomst heeft gesloten met een aandeelhouder met een eigen financieel belang. ${ }^{37}$

Om te voorkomen dat de bedenktijd oneigenlijk wordt gebruikt, bevat het wetsvoorstel enkele waarborgen. Zo vindt het inroepen van de bedenktijd door de vennootschap plaats door een met redenen omkleed besluit van het bestuur. Is er een $\mathrm{RvC}$, dan dient de RvC dit besluit tot inroeping goed te keuren. Er valt mijns inziens iets voor te zeggen dat de $\mathrm{RvC}$ dit inroeprecht ook dient te krijgen. In de memorie van toelichting is hierover evenwel opgenomen dat het volgens de regering het meest passend is om het bestuur te laten beslissen over het inroepen van de bedenktijd, juist gelet op het beleids- en strategieprimaat dat bij het bestuur rust. Daarom is afgezien van het opnemen van een zelfstandige bevoegdheid van de $\mathrm{RvC}^{38}$ Dit vind ik geen overtuigend argument. Met de voorgestelde regeling wordt immers beoogd om een beursvennootschap meer tijd en rust te gunnen voor de inventarisatie en weging van belangen van de onderneming en haar stakeholders. Er is dan gedurende deze fase juist (nog) geen sprake van aanpassing van beleid en strategie. Deze rol voor de RvC sluit bovendien aan bij de ontwikkeling in de overnamepraktijk, waarin regelmatig een special committee wordt samengesteld, met daarin ook commissarissen, dat een sturende rol kan hebben bij de onderhandelingen met (potentiële) bieders. ${ }^{39}$ Ingeval de $\mathrm{RvC}$ ook de bedenktijd kan inroepen, is dat voorts eveneens nuttig als twijfel bestaat of sprake is van tegenstrijdig belang bij het bestuur, omdat de $\mathrm{RvC}$ dan de bedenktijd kan inroepen. Ten slotte, als bestuur en $\mathrm{RvC}$ verschillend denken over het inzetten van de bedenktijd (maar nog wel door één deur kunnen), kan het nuttig zijn dat de $\mathrm{RvC}$ ook de bedenktijd kan inroepen in plaats van direct over te moeten gaan tot het zware middel van schorsing van bestuursleden, voor zover statu-

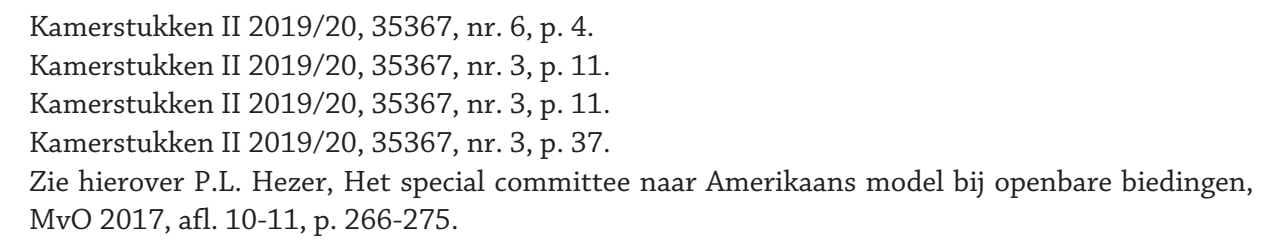


